\title{
ENHANCING INTER-KOREAN ECONOMIC COOPERATION THROUGH INTERNATIONAL CLUSTER: IMPLICATIONS FOR THE KAESONG INDUSTRIAL COMPLEX
}

\author{
Hwy-Chang Moon ${ }^{1}$ Wenyan Yin² \\ Seoul National University/ Seoul School of Integrated Sciences and Technology (aSSIST)
}

\begin{abstract}
In spite of the high potential of economic cooperation between the two Koreas, political tensions and international sanctions have discouraged the sustainability of economic outcomes. To overcome these political challenges, this article introduces two frameworks of international cluster and global value chains (GVCs) for developing effective and sustainable economic exchanges. These frameworks are applied to the case of the Kaesong Industrial Complex (KIC) and analysis of the reasons for its failure is provided. This article then suggests two strategic solutions for the KIC: minimizing the role of North Korea to a few GVC activities, and encouraging more foreign companies' investment. Unlike preceding studies that overemphasize the political challenges in inter-Korean economic relationships, we emphasize that an effective approach through internationalization can not only contribute to sustainable economic development but also ease political tensions.
\end{abstract}

Keywords: Economic cooperation, Kaesong Industrial Complex, South Korea, North Korea, international cluster, global value chains

Título en Castellano: La mejora de la cooperación económica intercoreana a través de agrupaciones internacional: implicaciones para el complejo industrial de Kaesong.

\section{Resumen}

A pesar del alto potencial de cooperación económica existente entre las dos Coreas, las tensiones políticas y las sanciones internacionales han desalentado la sostenibilidad de los resultados económicos. Para superar estos desafíos políticos, este artículo presenta dos marcos de agrupación internacional y cadenas de valor globales (CGV) para desarrollar intercambios económicos eficaces y sostenibles. Estos marcos se aplican al caso del Complejo Industrial de Kaesong (KIC) y se realiza un análisis de las razones de su fracaso. Este artículo sugiere entonces dos soluciones estratégicas para el KIC: minimizar el papel de Corea del Norte reduciéndolo a algunas actividades de CGV y alentar la inversión de más empresas extranjeras. A diferencia de estudios anteriores que enfatizan en exceso los desafios políticos en las relaciones económicas intercoreanas, señalamoss que un enfoque eficaz a través de la internacionalización no sólo puede contribuir a un desarrollo económico sostenible, sino también a reducir las tensiones politicas.

Palabras Clave: Cooperación Económica, complejo industrial de Kaesong, Corea del Sur, Corea del Norte, agrupaciones internacionales, cadenas de valor global

\section{Copyright @ UNISCI, 2019.}

Las opiniones expresadas en estos artículos son propias de sus autores, y no reflejan necesariamente la opinión de UNISCI. The views expressed in these articles are those of the authors, and do not necessarily reflect the views of UNISCI.

\footnotetext{
${ }^{1}$ Hwy-Chang Moon (Ph.D.) is Professor Emeritus, Graduate School of International Studies, Seoul National University and Chair Professor, Seoul School of Integrated Sciences and Technology (aSSIST),

E-mail: <cmoon.snu@gmail.com>

${ }^{2}$ Wenyan Yin (Ph.D.) is Visiting Professor at Seoul School of Integrated Sciences and Technology (aSSIST)

E-mail: <wenyanyin2012@gmail.com>

DOI: http://dx.doi.org/10.31439/UNISCI-78
} 


\section{Introduction}

Despite the official joint statement released in 1972 between the two Koreas, actual interKorean economic cooperation had not taken place until 1998 when President Kim Dae-jung of South Korea announced the "Sunshine Policy" in his inaugural speech" ${ }^{3}$ Over the last two decades, a number of agreements between the two Koreas have been reached in order to promote economic collaboration. However, such cooperation has been very sensitive to changes in the geopolitical environment, such as North Korea's nuclear tests and internal government policies ${ }^{4}$. The political environment has worsened rapidly since 2005 when North Korea declared its possession of nuclear weapons ${ }^{5}$. When a new conservative South Korean government under Lee Myung-bak began to pursue a tougher policy against North Korea from 2007, the political situation changed significantly and many cooperative projects were interrupted. For example, when a South Korean tourist was shot and killed by a North Korean soldier in 2008 at the Mount Kumgang Tourist Complex, tours to the resort were suspended. After the South Korean naval ship Cheonan was sunk by a North Korean submarine in 2010, the South Korean government cut off all inter-Korean projects except for the Kaesong Industrial Complex (KIC). However, after North Korea's fourth nuclear test in 2016, the South Korean government eventually closed down the Kaesong complex, which was the last vestige of interKorean cooperation ${ }^{6}$.

The situation though has improved recently. The April 2018 inter-Korean summit and the joint statement released provided additional hope for boosting exchanges between the two Koreas. Both governments have agreed to expand the scope of economic cooperation including plans to reopen the KIC and Mount Kumgang tourism project. Yet the experiences from the past two decades have shown that such a joint agreement by itself is no guarantee for the sustainable development of inter-Korean relations. We need to find a practical and effective approach to help the normalization and sustainability of ties between the two Koreas. Given the fact that North Korea is unwillingly to open up its entire economy, developing specific sites such as special economic zones to promote the growth of market economy and international exchanges and cooperation could be a more viable option for both Koreas.

In fact, North Korea has initiated a dozen specialized economic zones since the early 2000s after Kim Jong-Il's visits to China, and pursued a series of reforms for benchmarking China's successful experiences. Moreover, over the past decade, despite escalating political tensions, both governments rarely interrupted the operations of the complex before its drastic closure in 2016. This highlights the important role of KIC in not only easing the political tensions but also sustaining economic growth for both countries. Ong (2006) once stressed the important role of developing special economic zones in easing geopolitical tensions on the Korean Peninsula and stimulating the interactions economically and politically ${ }^{7}$. To this end, this article contributes to the extant literature on the inter-Korean economic integration with the focus on the KIC. From the international business perspective, this article recommends strategic guidelines for developing a win-win relationship for all parties involved in the project of

\footnotetext{
${ }^{3}$ Chang, Semoon: "Economic Cooperation between the Two Koreas", North Korean Review, Vol.8, n” 2 (December 2012), pp. 6-16.

${ }^{4}$ Doucette, Jamie and Lee, Seung-Ook: "Experimental Territoriality: Assembling the Kaesong Industrial Complex in North Korea”, Political Geography, Vol. 47 (July 2015), pp. 53-63.

${ }^{5}$ Chang, Semoon, op. cit., p. 8.

${ }^{6}$ You, Jeehye: "Legislative Reform of the Kaesong Industrial Complex in North Korea", Journal Pacific Basin Law Journal, Vol. 29, nº 1 (June 2011), pp. 36-74.

${ }^{7}$ Ong, Aihwa (2006): Neoliberalism as Exception: Mutations in Citizenship and Sovereignty, Chapel Hill, Duke University Press.
} 
economic cooperation through developing the platforms of international clusters and global value chains (GVCs).

The rest of this is organized as follows. It first reviews the existing literature on interKorean economic cooperation through the KIC, by focusing on the main reasons behind its failure. It then introduces two frameworks in the field of international business which are international cluster and GVCs. This article then proceeds to apply the two frameworks and provides strategic guidelines for the future development of the complex or developing other similar complexes between the two Koreas. Finally, the contribution and implications for the sustainable development of inter-Korean economic partnership will be addressed.

\section{Literature review}

The KIC opened in 2004 and ceased operations in 2016. Throughout that time, it was the largest economic project undertaken by the two Koreas ${ }^{8}$. The KIC has been an important part of North Korea's economic reform and has also played a significant role in maintaining peaceful relations at both regional and international level ${ }^{9}$. Given its important position in history, it has attracted a much attention among scholars across various aspects, such as the motivations, plans and incentives provided for the participating firms in the complex, the actual performance, and challenges. This section focuses on the examination of the key challenges and reasons behind the failure of the complex argued by the preceding studies.

Wrobel ${ }^{10}$ argued that in contrast to the manifold economic influences toward North Korea, the benefits for the South Korean side were not significant. Specifically, most of the investors in the KIC are uncompetitive South Korean small and medium-sized enterprises (SMEs) engaged in labor-intensive industries, such as textile and clothing industry. Their investment activities in this complex were driven by exploiting North Korea's cheap labor and were deeply dependent on the South Korean government's financial support and incentives, which included subsidies and political risk insurance. Wrobel pointed out that the economic advantages of the KIC for the South Korean side are very small and the whole Kaesong project is politically-driven by the South Korean government to facilitate unification.

You ${ }^{11}$ has recognized the legislative flaws of the KIC that have left businesses and individuals unprotected and threatened its very existence. She identified three legislative problems including (1) flaws in the statutory text such as the lack of sufficient regulations and vague language that can trigger misreading among the interested parties, (2) questions regarding the effectiveness of KIC laws in terms of their incomplete nature and the danger of legal intervention by the North Korean government, and (3) inadequate dispute resolution provisions in terms of the scope and methods. Therefore, these legislative problems have become an obstacle toward attracting investment from a broader field of investors into the KIC.

Haggard and Noland ${ }^{12}$ also highlighted the influences of North Korea's weak institutions on South Korean firms' modalities of entry and operations. The authors found the South Korean government has socialized such risks from through a variety of subsidies, insurance policies, and other preference measures. However, this reduces the autonomy of

\footnotetext{
${ }^{8}$ Cooper, Joanna: "Book review: Kaesong Industrial Complex, History, Pending Issues, and Outlook", North Korean Review, Vol. 5, n 1 (June 2009), pp. 133-134.

${ }^{9}$ You, Jeehye, op. cit., p. 47.

${ }^{10}$ Wrobel, Ralph M.: "Ten years of Kaesong Industrial Complex: A Brief History of the Last Economic Cooperation Project of the Korean Peninsula", Economic and Environmental Studies, Vol. 14, no 2 (June 2014), pp. 125-148.

${ }^{11}$ You, Jeehye, op. cit., p. 36.

12 Haggard, Stephan and Noland, Marcus: "The Microeconomics of North-South Korean Cross-Border Integration", International Economic Journal, Vol. 26, nº 3 (August 2012), pp. 407-430.
} 
firms' decision making based on their interests. Similarly, Doucette and Lee ${ }^{13}$ stressed the influences of the institutional environment by highlighting the volatile geopolitical situation that has led to slowdowns and restrictions on the entry and exit of goods and people. The authors argued that the volatility should not be attributed to the North Korean regime alone, but needs a new framework for enhancing stable and effective operations. They suggested that to expand the capacity and increase its internationalization by opening up the complex further.

Kelly ${ }^{14}$ raised the issue of how wages are paid, which has put off investment in the complex. Wages were paid to the North Korean government instead of their workers, and Pyongyang was thus able to capture US $\$ 100$ million a year. A substantial amount of this money was used by the North Korean regime to develop its nuclear weapons and missiles. Moreover, as this complex is highly restricted with almost no connection with the rest of North Korea, its impact on the country is limited. Hence, in contrast to the expected effects, the social and political benefits declined for both Koreas. Without resolving the dilemmas and issues, reopening and running a similar complex would be a vain effort.

On the other hand, Kim and Lim $^{15}$ identified two barriers to the KIC project between the two Koreas. One barrier is the incapacity of the North Korean government in sufficiently dealing with the tenant companies in terms of passage, communication, and customs clearance. Another barrier is the lack of facilities (dormitories and medical centers) necessary for the North Korean workers. These facilities, however, are difficult for South Korea and SMEs to tackle with, and this challenge further restricted the expansion of the complex to a higher stage.

Compared to the above-mentioned studies, $\mathrm{Nam}^{16}$ has emphasized more the marketoriented factors that help explain the hesitation to invest in the KIC among South Korean SMEs. These factors include a small market size for the host country due to the weak purchasing power of North Korea, and difficulty in entering the global export market, the US market in particular, due to the international sanctions against North Korea.

Although the focus on the above studies regarding challenges or obstacles of the stability and expansion of the KIC are different, they do overlap to some extent. In summary, this study reclassfies these challenges into four categories: (1) The dominance of South Korean SMEs in the labor-intensive industries and the lack of global investors from other countries, (2) small local market and difficulty in accessing the international market, (3) the lack of facility and infrastructure, and (4) weak North Korean institutions and volatile geopolitical environment. The fourth challenge has been mainly socialized by the South Korean government's policies, but it has shown to be less effective in dealing with inter-Korean tensions.

Doucette and Lee ${ }^{17}$ suggested expanding the complex by inviting more multinational corporations (MNCs) to minimize the risks involved by the South Korean government and firms. Such resolution could additionally help tackle the other three issues. By exploiting the global networks of these MNCs, South Korean SMEs are able to reach the global market and also their resources to invest in improving the necessary infrastructure. However, it cannot happen automatically, and an effective business environment is the key factor for attracting globally competitive $\mathrm{MNCs}^{18}$. There have been rare preceding studies that have pointed out the

\footnotetext{
${ }^{13}$ Doucette, Jamie and Lee, Seung-Ook, op. cit., p. 53.

${ }^{14}$ Kelly, Robert E.: "Re-Opening the Kaesong Industrial Zone Would Give North Korea Something for Nothing", The National Interest, 16 January 2019.

${ }^{15}$ Kim, Suk Hi and Lim, Eul-Chul: "The Kaesong Inter-Korean Industrial Complex: Perspectives and Prospects", North Korean Review, Vol. 5, no 2 (December 2009), pp. 81-92.

${ }^{16}$ Nam, Chang Woon: "Kaesong Industrial Complex: The Second Free Economic and Trade Area in North Korea", Internationales Asienforum, Vol. 43, n 3-4 (April 2012), pp. 351-371.

${ }^{17}$ Doucette, Jamie and Lee, Seung-Ook, op. cit., p. 61.

${ }^{18}$ Moon, Hwy-Chang (2016a): Foreign Direct Investment: A Global Perspective, Singapore, World Scientific.
} 
strategic direction for improving the business environment of the KIC by encouraging investment from global firms. In this respect, this study introduces two strategic tools for the effective reopening of the complex and expanding the linkage with non-Korean markets. The details will be explained in the following section.

\section{Strategic Tools for Effective Internationalization: GVCs and International Cluster}

\subsection{Global Value Chains: The new pattern of competition among MNCs}

The concept of the Global Value Chains (GVCs) is an extension of Porter's value chain framework ${ }^{19}$ from two aspects - the location of value chain activities and method of performing the value chain activities ${ }^{20}$. The first aspect is to expand the location of the MNCs' value activities from domestic to global scope. Porter mainly emphasized the benefits of locating the entire value chain in one specific region within the national context. However, due to the improvement in IT and transportation technologies, MNCs can gain higher productivity and effectiveness by spreading their activities abroad where they can most effectively implement those activities. The second aspect is to expand the modality of carrying out each value activity from a single firm to a network of firms through partnership with the external firms. Porter mainly stressed the benefits of dominating the entire value chain by a single firm. However, nowadays MNCs tend to disaggregate their firm value chain and outsource some activities to the firms that have higher competitiveness in carrying these activites ${ }^{21}$. Through the GVC strategy, MNCs thus can enhance their competitiveness and maximize their profits with minimum inputs.

\subsection{Two types of international clusters}

When MNCs choose to invest in developed or developing countries, they are not just looking at a single advantageous factor of the host country, such as natural resources or cheap labor. Instead, they prefer the location that facilitates or enhances the efficiency in performing the value chain activities. Yet, such location is not an entire country, but often a specific region within a country, or a business cluster. Michael Porter's work on clusters has been the most influential and has become the standard in this field of study ${ }^{22}$. However, Porter's (1990) cluster concept ${ }^{23}$ is limited to the domestic context, and cannot satisfactorily explain the growing linkage among clusters across national borders.

In this respect, Moon and Jung ${ }^{24}$ introduced a four-stage cluster model by expanding Porter's cluster theory from domestic to the international scope. According to Moon and Jung, the international cluster is further divided into two types which are international-linking and global-linking clusters. The international-linking clusters emphasize the linkage among clusters from neighboring countries for creating synergies in terms of technology, capital, and human resources. A good example is SIJORI growth triangle (Singapore, Johor in Malaysia, and Riau in Indonesia) in Southeast Asia. On the other hand, the global-linking clusters leverage close linkages between each other on the global scale, regardless of the physical distance between them. The global linkage between the US Silicon Valley and India's Bangalore IT cluster is a

\footnotetext{
${ }^{19}$ Porter, Michael E. (1985): Competitive Advantage: Creating and Sustaining Superior Performance, New York, Free Press.

${ }^{20}$ Yin, Wenyan (2017): "Global Value Chain: Theoretical Integration, Extension, and Empirical Analysis", Unpublished Ph.D. dissertation, Seoul National University.

${ }^{21}$ Yin, Wenyan: "A New Model for Globalization in the Film Industry: Lessons from China-Hollywood Film Coproduction”, Kritika Kultura, Vol. 32 (February 2019), pp. 117-140.

${ }^{22}$ Moon, Hwy-Chang (2018): The Art of Strategy: Sun Tzu, Michael Porter, and Beyond, Cambridge, Cambridge University Press.

${ }^{23}$ Porter, Michael. E. (1990): The Competitive Advantage of Nations, New York, Free Press.

${ }^{24}$ Moon, Hwy-Chang and Jung, Jin-Sup: "Northeast Asian Cluster through Business and Cultural Cooperation", Journal of Korea Trade, Vol. 14, nº 2 (June 2010), pp. 29-53.
} 
notable example. Due to its advantages in global linkage, most of the globally competitive multinationals have been based or connected with Silicon Valley ${ }^{25}$.

\section{Strategic guidelines for improving inter-Korean economic cooperation through cluster and GVC approach}

The KIC is located in the city of Kaesong in North Korea. Hence it accords with Porter's concept of domestic cluster, without any linkages with other clusters within North Korea or abroad. The complex was designed to attract the investment of South Korean SMEs that are engaged in the light industry. According to a recent study by Haggard and Noland ${ }^{26}$, at its peak in the late 2000s, there were about 400 South Korean firms doing business in this complex. Most of them were small firms with less than 10 employees, and only a few were large firms with more than 1,000 employees. Moreover, most of these targeted the South Korean market, instead of exporting to other countries. There have been very few non-Korean firms engaged in investment in the complex. Due to the political risks, foreign firms would rather invest in the KIC together with South Korean firms than establishing joint ventures with North Korean firms alone $^{27}$.

The low degree of internationalization of the KIC has lowered its bargaining power over the North Korean side and has also shown vulnerability to changes in the geopolitical environment. Moreover, Wrobel ${ }^{28}$, s study found that the dominant position of light industry in the complex has not generated significant economic benefits and enhanced its competitiveness in the international market. In this respect, based on the two concepts of international clusters and GVCs aforementioned, this article introduces two principles-increasing internationalization and commercialization of the complex - which should be the future viable direction for the suitable development of the complex and the effective inter-Korean economic cooperation. More details in this case will be discussed below.

To increase the degree of internationalization of the complex, the two Korean governments will need to attract globally competitive MNCs. As illustrated before, MNCs tend to spread their value chain activities around the world instead of concentrating the entire chain in one region. They also prefer international oriented clusters instead of the domestically oriented ones. The KIC needs to extend the scope of its cluster from local to international one which is competitive enough to host part of the value chain activities of the global MNCs, by exploiting North Korea's locational advantages. In order to enhance the internationalization and attractiveness of the complex to a higher level, firms should be able to come and go smoothly, and thus both inward and outward foreign direct investment (FDIs) are encouraged for enhancing the overall effectiveness of the MNCs' GVCs. MNCs will then serve as the bridge linking the KIC with other international clusters from China and other countries. This will in turn facilitate the development of the KIC to an international-linking cluster and attract more FDI from foreign firms.

In this vein, Vietnam's successful experiences in developing international clusters can be a good benchmarking case. By May 2016, Vietnam had more than 300 industrial and economic zones, which contributed to attracting billions of dollars in FDI inflows. Korean MNCs, which are the largest investors in Vietnam, were particularly concentrated in the industrial and economic zones of the northern part of the country near Hanoi, and the southern

\footnotetext{
${ }^{25}$ Moon, Hwy-Chang: "The strategy for Korea's Economic Success: Innovative Growth and Lessons from Silicon Valley" [in Korean], Review of International and Area Studies, Vol. 26, nº 3 (September 2017), pp. 1-33.

${ }^{26}$ Haggard, Stephan and Noland, Marcus, op. cit., p. 409.

${ }^{27}$ Lim, Eul-chul: "Legal Reforms and Foreign Investment in the Inter-Korean Project: The Kaesong Industrial Complex", North Korean Review, Vol.4, n 1 (June 2008), pp. 26-39.

${ }^{28}$ Wrobel, Ralph M., op. cit., p. 143.
} 
part near Ho Chi Minh City. This is because the clusters in the two areas have extensive international linkages with neighboring countries which help Korean firms facilitate connections with their global value chain activities across borders. Specifically, northern Vietnam has locational advantage for firms importing input goods, such as parts and components, from China. In a similar vein, southern Vietnam has the advantage of proximity to the Southeast Asian market.

Korean MNCs not only expand their investments in terms of the volume of FDI, but also the quality of FDI by locating more high-value added activities in Vietnam. Korean FDI in Vietnam after 2008 financial crisis was initiated by establishing large-scale assembly plants (labor intensive activity) for electronic goods, but more recently, investments by firms such as Samsung Electronics are shifting to more technology and capital-intensive activities, such as building R\&D centers andmanufacturing high value-added parts and components. The upgrade not only occurs within the same industry (i.e., electronics), but across industries by expanding from manufacturing to other service industries such as construction and distribution for wholesale and retail. The growing manufacturing sector creates more business opportunities for other industries, including real estate, construction, and distribution.

The successful case of Vietnam thus illustrates the importance of the internationallinking cluster in attracting FDI and the upgrade in quality of investment as well. In this sense, the KIC can link with the clusters from neighboring countries such as China, Japan, and Southeast Asian countries, and even distant countries from Europe can complement the comparative advantages of North Korea, thereby enhancing its strengths while complementing its weaknesses. Such international or global linkages can solve the previous problem of targeting the South Korean market only.

In addition to improving the internationalization degree of the KIC by encouraging more investment from foreign companies, the South Korean government should also make sure to improve the commercialization yet minimize the role of North Korea to a few GVC activities. It is critical that commercialization helps North Korea continuously gain the economic benefits by joining these cooperative projects. However, at the same time, minimizing the role of North Korea can help South Korea be less vulnerable to intervention and negative influences on the whole project. North Korea can be invited to participate in the partial or low value-added activities across the chain. Therefore, if it withdraws or breaks down any linkage within the value chain, it will lose the potential of making money. Furthermore, since MNCs only locate part of their value activities in North Korea, it will be less likely for the North Korean authorities to control or influence the whole value chain. Such a strategic approach will help foreign MNCs reduce the negative effects of an uncertain environment.

Regarding the effective operations of the complex, this article provides strategic directions by using the suggestions from Moon $^{29}$ for developing the competitive internationallinking clusters. The cluster should be driven by the business objective, and governed by the internationally independent institutions, rather than political interests based on governmental cooperation. For this, all the rules and regulations should follow the global standard, and provide a favorable business environment with minimum regulations. This is particularly important to attract globally competitive MNCs from various sectors of both manufacturing and services.

Given the satisfaction of two principles for enhancing the attractiveness of the complex mentioned before, the North Korean authorities will be more likely to participate in the development of international-linking cluster and follow the global standard and rules, thereby

\footnotetext{
${ }^{29}$ Moon, Hwy-Chang (2016b): The Strategy for Korea's Economic Success, New York, Oxford University Press.
} 
maximizing the benefits for all parties involved in the complex. People often mention that geopolitical uncertainty and risks are uncontrollable factors, but through these alternative strategies we can circumvent them and even effectively manage these uncontrollable factors. Due to the large gap in terms of economic, social, and political spheres, the successful development of the complex can thus play an important role as a buffer zone for integrating the Korean Peninsula.

\section{Conclusion}

Despite the importance of the KIC in developing the strategic relationship between the two Koreas, it has failed to achieve win-win results for both countries. The KIC has particularly failed to realize the expected economic benefits for South Korean SMEs. Although the complex was closed in 2016, it is meaningful to identify the reasons behind the failures and provide effective solutions to respond and prepare future economic cooperation between the two Koreas. There have been many preceding studies concerning the challenges or reasons for failures of the KIC. However, few have suggested any satisfactory resolution. Many have emphasized the key role of governments in providing the institutional and financial support for investors. However, past experiences have shown that strong government intervention or politically oriented clusters have not been successful in attracting foreign investors to this complex. On the other hand, some scholars attributed the failure to the uncertain geopolitical environment. However, since this factor is uncontrollable, in order to overcome the difficulty and sustain inter-Korean relations, strategic guidelines should be more focused on the controllable aspects.

This article has argued that enhancing the degree of internationalization of the complex is the key toward enhancing the effectiveness of cooperation. Specifically, we have introduced two key tools of internationalization - international clusters and GVCs. Developing the international clusters by creating synergy through cross-border clusters can form a platform to attract globally competitive MNCs. On the other hand, the GVC framework helps us understand how to achieve the commercialization goal for all participants while minimizing the role of North Korea to a few GVC activities, thereby restricting the negative influences and vulnerability from political threats. In order to better understand this approach, this article shows the successful example of Vietnam in attracting FDI and satisfying the demand of both global investors and the involved governments. The proposed guidelines should not be limited to the Kaesong complex but can also be used for other economic cooperative projects between the two Koreas.

\section{Bibliography}

Chang, Semoon: "Economic Cooperation between the Two Koreas", North Korean Review, Vol.8, no 2 (December 2012), pp. 6-16.

Cooper, Joanna: "Book Review: Kaesong Industrial Complex, History, Pending Issues, and Outlook", North Korean Review, Vol. 5, nº 1 (June 2009), pp. 133-134.

Doucette, Jamie and Lee, Seung-Ook: "Experimental territoriality: Assembling the Kaesong Industrial Complex in North Korea”, Political Geography, Vol. 47 (July 2015), pp. 53-63.

Haggard, Stephan and Noland, Marcus: "The Microeconomics of North-South Korean CrossBorder Integration”, International Economic Journal, Vol. 26, no 3 (August 2012), pp. 407430. 
Kelly, Robert E.: "Re-Opening the Kaesong Industrial Zone Would Give North Korea Something for Nothing", The National Interest, 16 January 2019.

Kim, Suk Hi and Lim, Eul-Chul: "The Kaesong Iner-Korean Industrial Complex: Perspectives and prospects", North Korean Review, Vol.5, no 2 (December 2009), pp. 81-92.

Lim, Eul-chul: "Legal Reforms and Foreign Investment in the Inter-Korean Project: The Kaesong Industrial Complex", North Korean Review, Vol. 4, nº 1 (June 2008), pp. 26-39.

Moon, Hwy-Chang (2016a): Foreign Direct Investment: A Global Perspective, Singapore, World Scientific.

Moon, Hwy-Chang (2016b): The Strategy for Korea's Economic Success, New York, Oxford University Press.

Moon, Hwy-Chang (2018): The Art of Strategy: Sun Tzu, Michael Porter, and Beyond, Cambridge, Cambridge University Press.

Moon, Hwy-Chang: “The Strategy for Korea's Economic Success: Innovative Growth and Lessons from Silicon Valley" [in Korean], Review of International and Area Studies, Vol. 26, no 3 (September 2017), pp. 1-33.

Moon, Hwy-Chang and Jung, Jin-Sup: "Northeast Asian Cluster through Business and Cultural Cooperation”, Journal of Korea Trade, Vol. 14, nº 2 (June 2010), pp. 29-53.

Nam, Chang Woon: "Kaesong Industrial Complex: The Second Free Economic and Trade Area in North Korea”, Internationales Asienforum, Vol. 43, n 3-4 (April 2012), pp. 351-371.

Ong, Aihwa (2006): Neoliberalism as Exception: Mutations in Citizenship and Sovereignty, Chapel Hill, Duke University Press.

Porter, Michael E. (1985), Competitive Advantage: Creating and Sustaining Superior Performance, New York, Free Press.

Porter, Michael. E. (1990): The Competitive Advantage of Nations, New York, Free Press.

Wrobel, Ralph M.: "Ten Years of Kaesong Industrial Complex: A Brief History of the Last Economic Cooperation Project of the Korean Peninsula", Economic and Environmental Studies, Vol. 14, n 2 (June 2014), pp. 125-148.

Yin, Wenyan (2017): “Global Value Chain: Theoretical Integration, Extension, and Empirical Analysis”, Unpublished Ph.D. dissertation, Seoul National University.

Yin, Wenyan: “A New Model for Globalization in the Film Industry: Lessons from Sino-US Film Co-productions”, Kritika Kultura, Vol. 32 (February 2019), pp. 117-140.

You, Jeehye: "Legislative reform of the Kaesong Industrial Complex in North Korea", Journal Pacific Basin Law Journal, Vol. 29, nº 1 (June 2011), pp. 36-74. 